https://doi.org/10.5719/aub-g/69.1/5

\title{
EXTREME HEATING IN CITIES OF THE ROMANIAN PLAIN. CERTAINTIES AND UNCERTAINTIES ABOUT THE FACTORS OF INFLUENCE
}

\author{
CĂTĂLINA MĂRCULEȚ ${ }^{1}$, FLORINA GRECU ${ }^{2}$, \\ SORIN CARABLAISA $\breve{A}^{3}$, CRISTINA DUMITRICĂ ${ }^{1}$
}

\begin{abstract}
The paper presents the extreme heating, highlighted in the form of the days with temperature $\geq 35^{\circ} \mathrm{C}$, in the Romanian Plain, one of the territories of Romania with the most intense heating. The study is based on the processing of daily data of the maximum air temperature, registered by the National Meteorological Administration, for the stations located in 7 cities of the Romanian Plain. These extreme situations were analyzed by: calculating the total number of days gathered year by year and extracting the periods with such successive days of different durations, calculating their frequencies for the analyzed period, identifying the maximum duration intervals of each year and outlining their evolution trends. The extreme intensity of the heating, represented by the absolute maximum values extracted from the entire period, are described by the manifestation data both in the air and on the ground. The extraordinary magnitude of the phenomena was also highlighted by the MODIS satellite data. At the end the factors that influence the occurrence of these extreme phenomena are recalled.

Keywords: extremes, heat, Romanian Plain, influence factors.
\end{abstract}

\section{Introduction}

In the Romanian Plain, 66 cities were developed with an unequal distribution in the territory, determined by a series of historical and

1 Institute of Geography of the Romanian Academy, Dimitrie Racoviță Str., No. 12, 023993, Sector 2, Bucharest, Romania. Email: catalina.marculet@gmail.com

2 University of Bucharest, Faculty of Geography, N. Bălcescu Bd., No. 1, sector 1, 010041, Bucharest, Romania. Email: grecu@geo.unibuc.ro

3 University of Bucharest, Faculty of Geography, Research Station Orşova, Romania. 
social factors and by those relief features that favored their appearance and development.

The exacerbation of extreme thermal phenomena, felt especially in the hot season of the year, is an indicator of the global warming trend. This major climatic danger has accelerated its intensity in the last years, the Romanian Plain being one of the most affected region of the country prone to intense heating.

Situation with extreme heating during the hot season of the year are highlighted in the form of days when the maximum temperatures reach and exceed the 35 Celsius degree threshold - extremely hot days. Those high air temperatures are reflected on the ground surface temperature (LST), which can exceed $60^{\circ} \mathrm{C}$, depending on the nature of the material exposed. If we focus on the constantly growing urban areas, where most of the population tend to live and work, we can detect some vulnerable areas that heat very fast during the day, and remain very hot even during the night that have a negative impact (Mărculeț, Dumitrică, 2020).

The main factor that determines the climate is the geographical position. Located in central-Eastern Europe, the Romanian Plain benefits from a temperate climate, the location of cities in various physicgeographical features introducing differences in the regime of climatic phenomena - several climatic shades. Depending to their geographic (geomorphologic) location the following cities alignments were identified (Grecu et al 2012a): cities along the contact with the Bending Subcarpathians and the Getic Tableland near rivers that widen their valleys once release from the hilly area, on their terraces as well as along the morphologic contact (in northern part of the region - e.g. Buzău); cities along the Danube (at the contact of the flood plain-terraces, e.g. Drobeta-Turnu Severin, Călărași, Galați); cities developed in the plain area, along morphologic-hydrologic or lake alignments (Bucharest Romania's capital city, Craiova); cities developed in the interfluve area (highlands) - usually small cities resulted from villages (e.g. Roșiorii de Vede) (Figure 1). 
EXTREME HEATING IN CITIES OF THE ROMANIAN PLAIN.

CERTAINTIES AND UNCERTAINTIES ABOUT THE FACTORS OF INFLUENCE

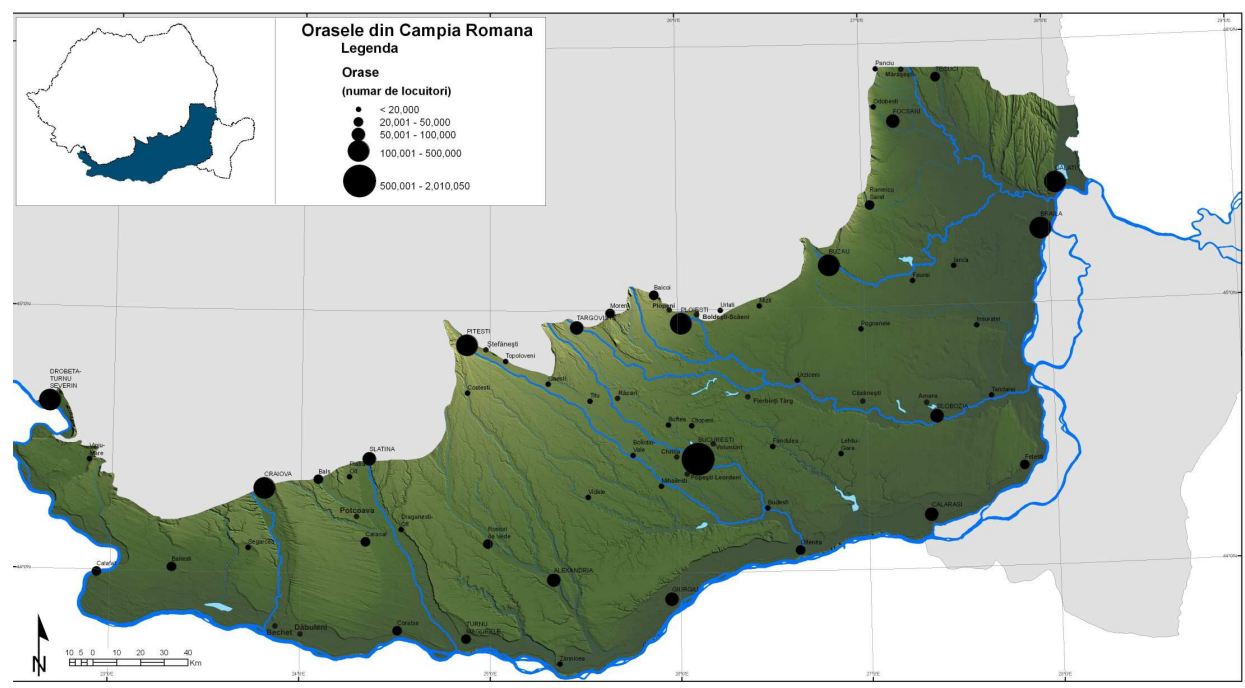

Fig.1. The cities of the Romanian Plain. Geographical position and size according to the number of inhabitants (Grecu et al 2012a)

\section{Data and Method}

Based on the meteorological data recorded by the National Meteorological Administration (ANM), available within the European Climate Assessment and Datasets project, the study started from processing the daily recordings of the maximum temperatures for a period of 55 years (1961-2015) of the 7 weather stations within the Romanian Plain: Bucharest-Băneasa, Buzău, Călărași, Craiova, Drobeta-Turnu Severin, Galați and Roșiorii de Vede.

First, the daily data permited a detailed analysis of the extremely hot situations by: calculating the total number of days gathered year by year and extracting the periods with such successive days of different durations, calculating their frequencies for the analyzed period, identifying the intervals with maximum duration of each year and outlining their evolution trends. Finally, the cases of extreme heat are specified, in which the absolute maximum values of each weather station for the period 1961-2015 have been reached. 
Considering the fact that the Romanian Plain has small altitudinal differences and an almost imperceptible variation of thermal values in the region, to obtain an adequate interpretation of the phenomena, a synthetic map was made using the cases of extremely hot days summed on the entire period of 55 years, providing thus a suggestive territorial distribution of the studied phenomena.

Also, in order to analyse the relationship between the components of the urban environment and the land surface temperature (LST) during the episodes of extreme heat for the selected cities two types of data were used: the landuse/cover data from the the CORINE Land Cover (CLC) 2000 and 2006 product of the Copernicus Land Monitoring Services provided by EU Copernicus programme and the LST from MOD11_L2 and MYD11_L2 products of MODIS satellite sensors TERRA and AQUA, which have a moderate spatial resolution $(500 \mathrm{~m}-1 \mathrm{~km})$, but a daily temporal resolution. The results obtained are meant to highlight the type of areas with highest thermal stress.

\section{Results}

The variability from year to year of the extremely hot consecutive days intervals, illustrated on the graphs constructed for each of the seven stations, indicated the recording of the increasing values in the last years - 2000, 2007 and 2012 (Figure 2).

The maximum intervals of extremely hot consecutive days show that almost all the situations were met in 2007, in the conditions of the hottest year of the studied period, the records lengths of 9-10 days with temperature $\geq 35^{\circ} \mathrm{C}$ being reached between 16-25 of July.

On the same graphs were compared the year-on-year evolution of the total number of extremely hot episodes (regardless of duration) and it is observed that years 2012, 2000 and 2007 represented also the highest peaks, with different values amounts from a station at another (Fig. 2).

The year 2007 represented a record in terms of lengths of extremely hot days intervals, while 2012 (2000 for Drobeta-Turnu Severin) are a record through number of such intervals. 
EXTREME HEATING IN CITIES OF THE ROMANIAN PLAIN.

CERTAINTIES AND UNCERTAINTIES ABOUT THE FACTORS OF INFLUENCE

These similar and parallel situations are highlighted by the outline of linear trends that show accentuated increases not only for the total number of such hot intervals, but also for their maximum durations. Among the most accelerated warming tendencies are observed at Drobeta-Turnu Severin, Galați, Buzău and Călărași.

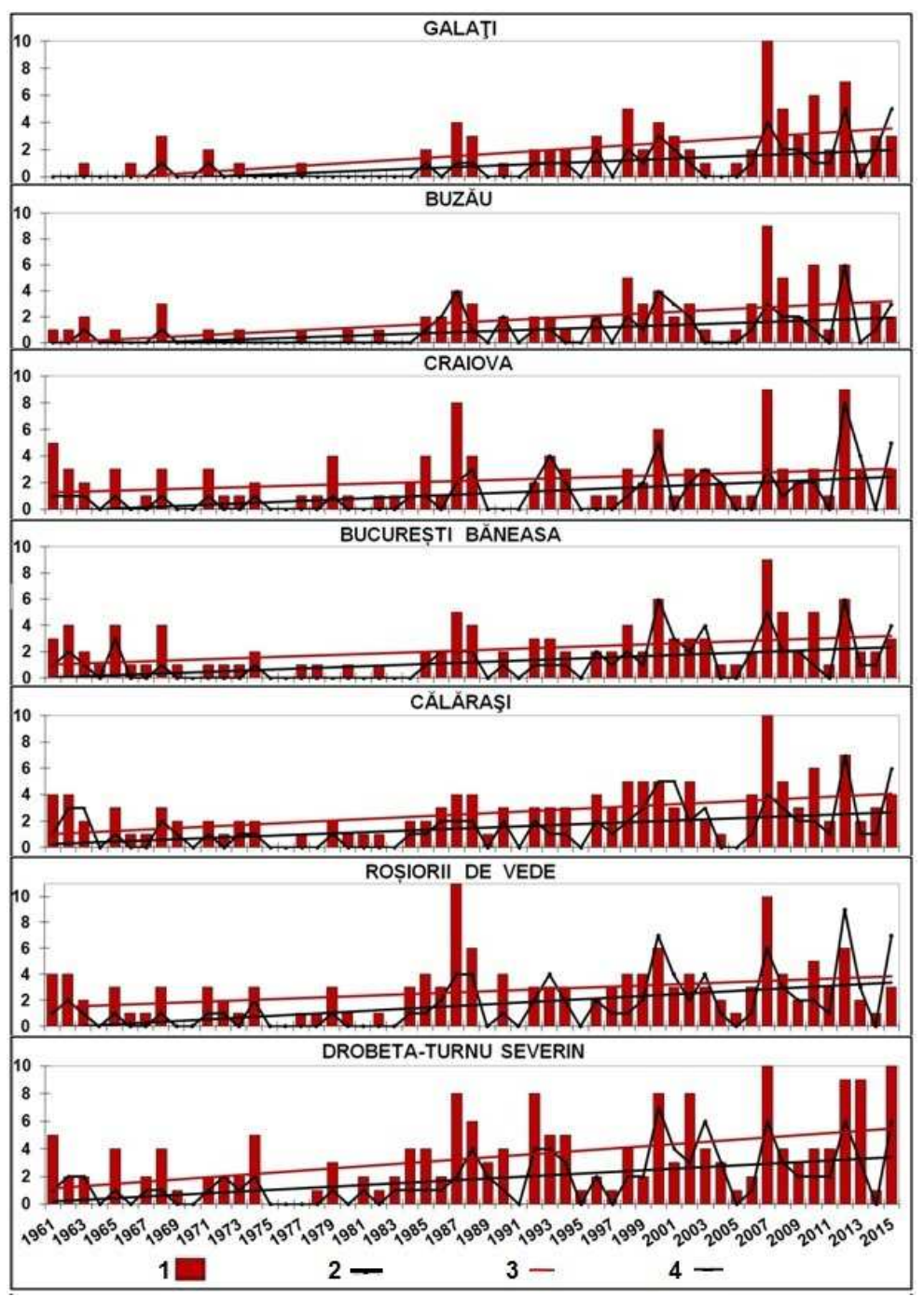

Fig. 2. Variation of extremely hot consecutive days intervals (1961-2015):

1. maximum duration of intervals; 2 . total number of intervals; 3 . linear evolution of maximum duration; 4 . linear evolution of the total number of intervals 
The absolute maximum values extracted from the entire period (1961-2015) exceeding $42^{\circ} \mathrm{C}$ at most of the analysed stations, except for Buzău and Galați, which exceed only $40^{\circ} \mathrm{C}$ threshold (table 1).

Absolute maximum values of temperature (1961-2015)

\begin{tabular}{|c|c|c|}
\hline Stations & Values $\left({ }^{\circ} \mathbf{C}\right)$ & Data of occurrence \\
\hline Roșiorii de Vede & 42,7 & 24 iulie 2007 \\
\hline Craiova & 42,6 & 24 iulie 2007 \\
\hline Drobeta-Turnu Severin & 42,6 & 4 iulie 2000 \\
\hline Călărași & 42,3 & 5 iulie 2000 \\
\hline București-Băneasa & 42,2 & 5 iulie 2000 \\
\hline Galați & 40,5 & 22 iulie 2007 \\
\hline Buzău & 40,3 & 23 iulie 2007 \\
\hline
\end{tabular}

From the data of occurrence of extreme heat at each station it is pointed out that years 2007 and 2000 represented break-records of the most intense heating.

The map of the territorial distribution of the total number of extremely hot days, summed throughout the whole period of observation, show large differences between the studied cities, the highest values being more than double compared to the smallest ones: Drobeta-Turnu Severin 441 days/period, Roşiorii de Vede - 368, Călărași - 348, Bucharest-Băneasa - 279, Craiova - 254, Buzău - 193 and Galați - 110 extremely hot days/period (Fig. 3).

Can be observed a generalised decreasing from west to east and from south to north, according with latitudinal and geographical position that conditioning the amount of solar radiation received on the ground and with the exposure at the tropical air advections which are registered more frequent from southwest direction. The local conditions of the stations introduce additional diversifications in the distribution of extreme heating phenomena. For example, in Galați, the proximity of the aquatic surfaces moderates the incidence of these extreme phenomena, while in Roşiorii de Vede the cumulation of the thermal stress with the hydric one induces the exacerbation of the heating. 


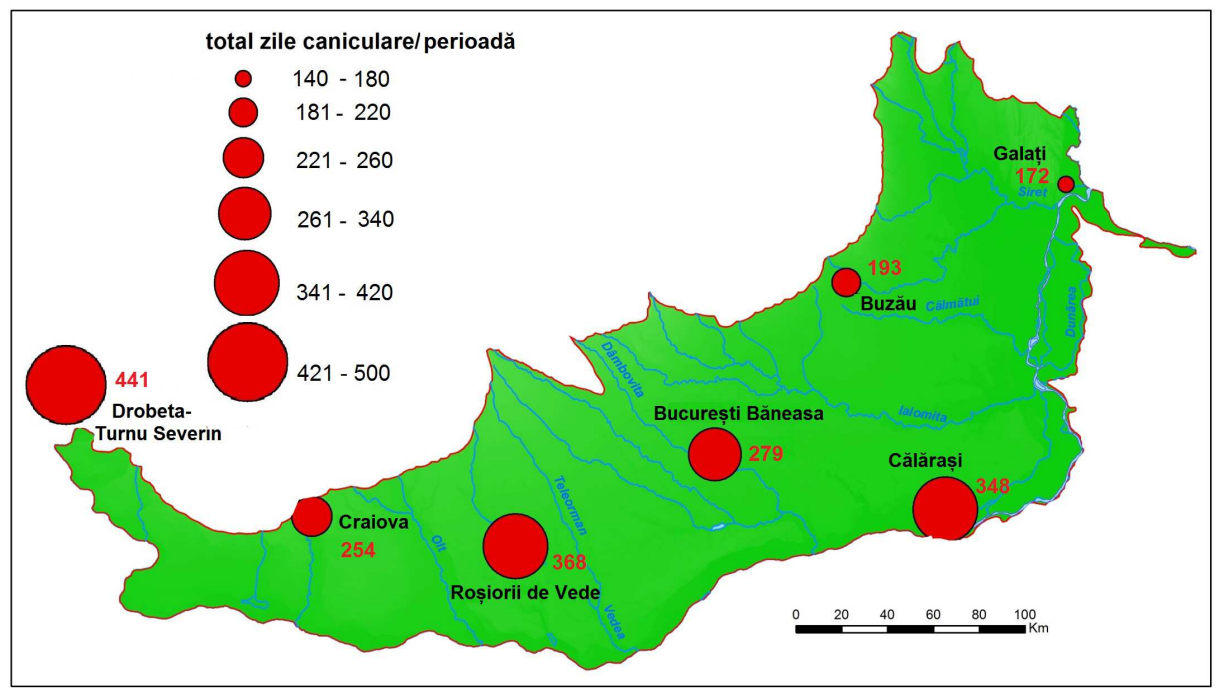

Fig. 3. Total number of extremely hot days/period (1961-2015)

During the record-breaking episodes of July 2000 and 2007, the exacerbation of heating culminated in exceeding the $40^{\circ} \mathrm{C}$ threshold in air at many weather stations in Romania.

At Drobeta-Turnu Severin the highest value of air temperature $\left(42.6^{\circ} \mathrm{C}\right)$ was recorded on July 4, 2000, in the conditions of hot air advection from North-Africa and the persistence of anticyclonic activitiy. These extreme values were registered during an episode of 7 consecutive extremely hot days, July 2-8, when maximum temperatures did not decrease under $35^{\circ} \mathrm{C}$.

From the MODIS satellite data available for July 4, 2000, the maximum daytime land surface temperature (LST) is visible (in red color) over the residential and industrial surfaces (in red and purple color, according with Corine Land Cover - CLC code). On the contrary, the surfaces covered with forests (green) and pastures (yellow) or situated near the Danube river water (blue) show lowest temperature. Middle values were registered over agricultural areas - arable lands or with permanent crops - north of residential areas (Figure 4).

The temperature inside the city are higher, making visible the urban heat island, with an amplitude of $2-6^{\circ} \mathrm{C}$ compared to the adjacent 
surfaces (Figure 4). The compact sealed areas within the city are the additional causes that have intensified this extreme heating.
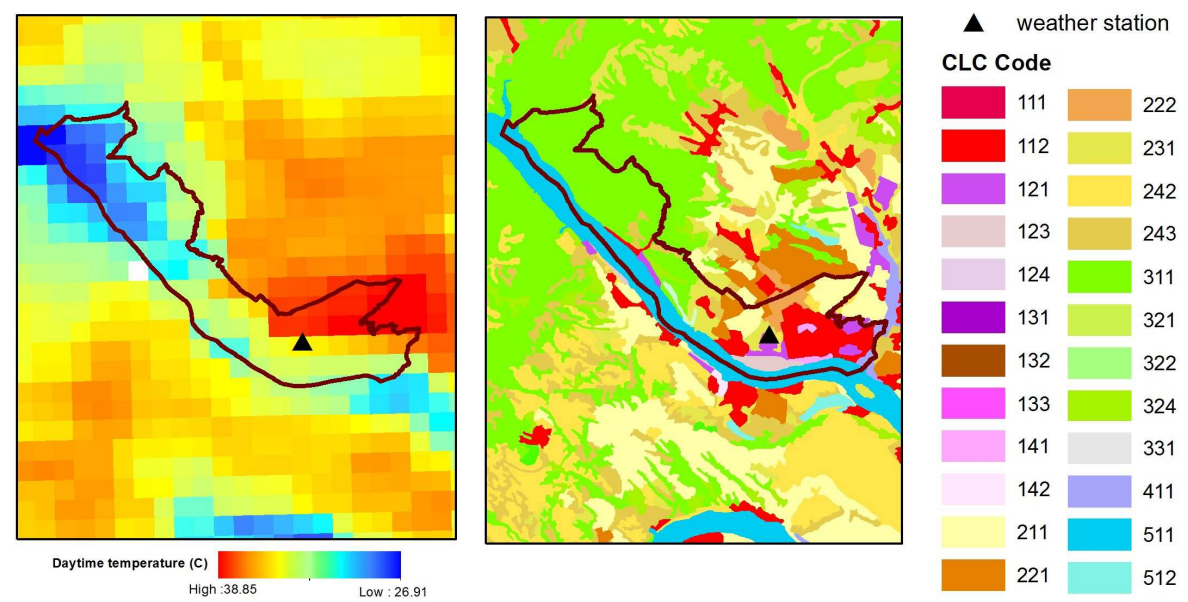

Fig. 4. Drobeta-Turnu Severin City: LST data for spatial variation of the temperature (left); distribution of the different types of surfaces (right) - CLC nomenclature according to Feranec et al, 2016

The episode of consecutive extremely hot days on mid-summer of the year 2000, comparing with Drobeta-Turnu Severin, was shorter at București-Băneasa and Călărași (between July 3-6) and the absolute maximum values of temperature reached $42.2^{\circ} \mathrm{C}$ and $42.3^{\circ} \mathrm{C}$, respectively, in July 5.

On the images from MODIS satellite of this break-record common day, can be found that the position of weather station is in the northern part of Bucharest city, near the forested area or covered with permanent crops, while the Călărași station is in residential area, accordingly to the CLC Code (Figure 5b, d). In both cities, the forests (in green), green urban areas (pink) and waters surfaces (blue) contributed to decrease the intensity of heating, but the urban and industrial surfaces were much warmer, resulting an amplitude up to $10^{\circ} \mathrm{C}$ (Figure 5). In the center of Bucharest, the maximum daytime land surface temperature (LST) was over $45^{\circ} \mathrm{C}$, much higher than the temperature registered at the weather station, indicating that the air temperature above the compact residential surfaces reached more than the official record meteo $-42,2^{\circ} \mathrm{C}$ (Figure 5a). 

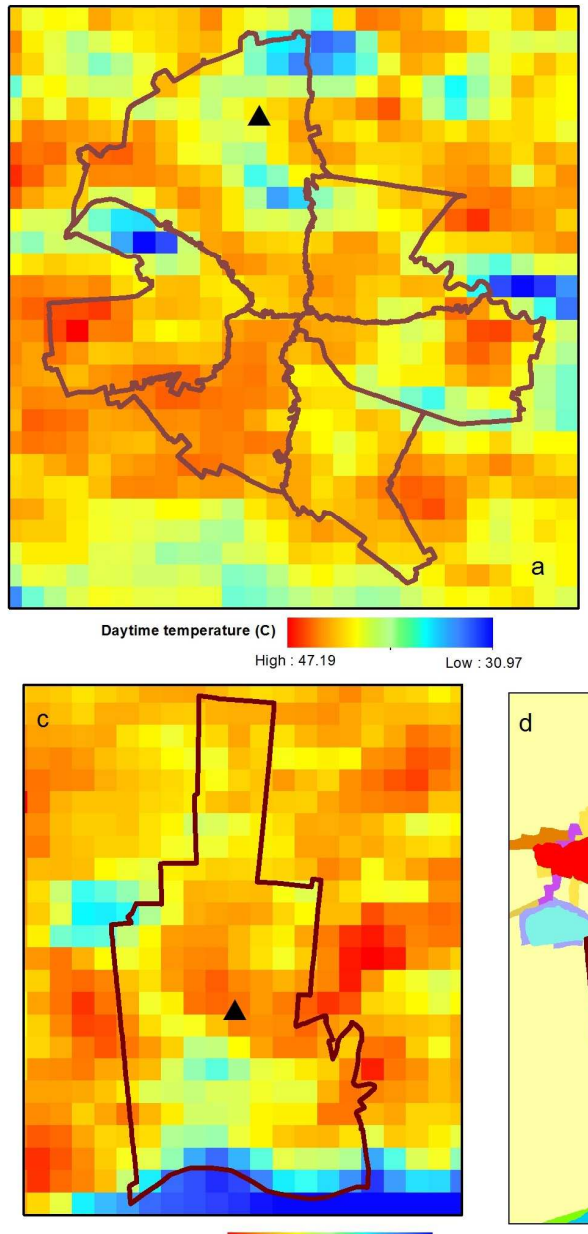

Daytime temperature (C)

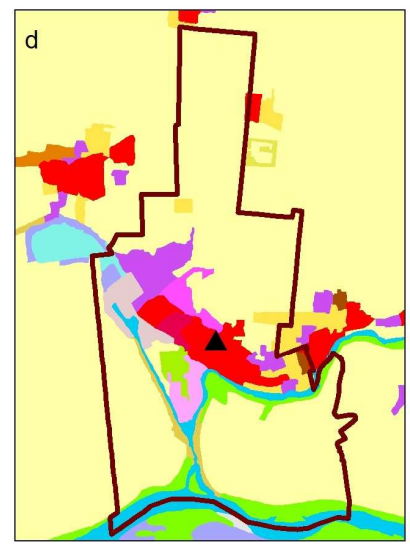

$\Delta$ weather station CLC Code

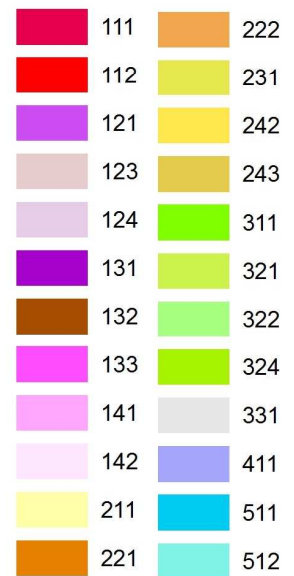

Fig. 5. Bucharest (top) and Călărași (below): LST data for spatial variation of the temperature $(a, c)$; distribution of the different types

of surfaces $(b, d)$ - CLC nomenclature according to Feranec et al, 2016

The second record-breaking of extreme heating was reached in the episode of July 2007, between 16-25, at Galați (on July 22), Buzău (on July 23), Craiova and Roșiorii de Vede (on July 24). Causes of this rare situation were the extraordinary extension of anticyclone that facilitate the advection of hot Saharian air from south-west, associated with the intensification of local insolation processes (Mărculeț, Mărășoiu, 2016). 
Comparing the images for Buzău and Galați, when the highest values of air temperature $\left(40.3^{\circ} \mathrm{C}\right.$ and $\left.40.5^{\circ} \mathrm{C}\right)$ in the entire analised period were reached at this weather stations, interesting differences can be observed between several type of surfaces.

The images for Buzău city, that show the situation of absolute extreme heat registered on 23 of July, 2007, relief that the highest values of the lands' surfaces temperature were specific over the arable lands and not on the artificial surfaces. These residential and industrial surfaces, that are in near areas with significant natural vegetation on the meadow of Buzău river, benefit of the moderation influences (Figure $6 a, b$ ).

On 22 of July, 2007, at Galați was registered lower values on the residential and industrial surfaces than over the agricultural areas, because the proximity of the aquatic surfaces (rivers and lakes) moderates the incidence of the extreme heat (Figure $6 \mathrm{c}, \mathrm{d}$ ).

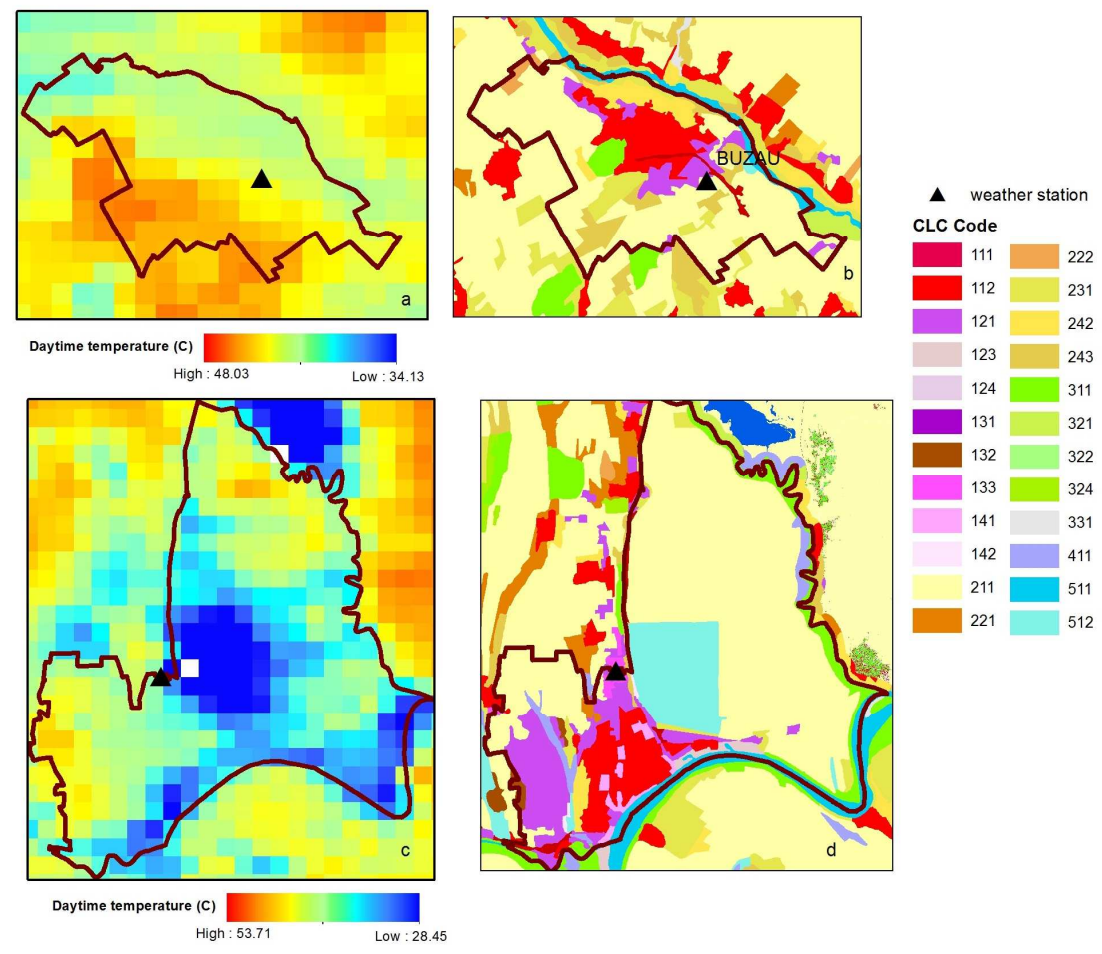

Fig. 6. Buzău (top) and Galați (below): LST data for spatial variation of the temperature $(\mathrm{a}, \mathrm{c})$; distribution of the different types of surfaces $(b, d)-C L C$ nomenclature according to Feranec et al, 2016 
EXTREME HEATING IN CITIES OF THE ROMANIAN PLAIN.

CERTAINTIES AND UNCERTAINTIES ABOUT THE FACTORS OF INFLUENCE

The absolute maximum values of temperature are lower at Buzău and Galați, and doesn't reach $42^{\circ} \mathrm{C}$ like at the other stations. This can be explained by the local characteristics of these two cities described above.

On July 24, 2007, at Craiova was recorded $42.6^{\circ} \mathrm{C}$, these extreme values being registered at the end of 9 consecutive extremely hot days.

On the image from the MODIS satellite data available for July 24, 2007, higher land surface temperatures (LST) are visible over the residential and industrial area. Outside the city, the surfaces covered with forests and pastures show the lowest temperatures (Figure 7a, b). Taking into account that the weather station is situated at the edge of the administrative boundary of Craiova, the temperature inside the city were even higher than $42.6^{\circ} \mathrm{C}$, due to the visible urban heat island (Figure 7a).

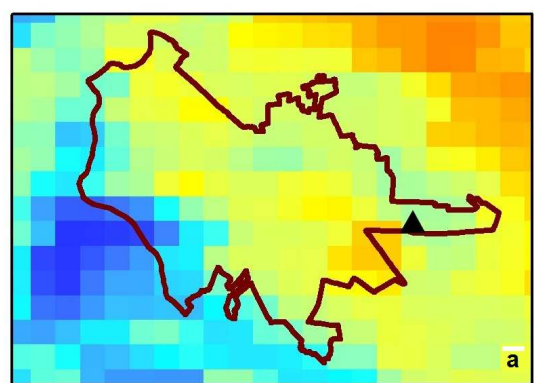

Daytime temperature (C) High : 43.85

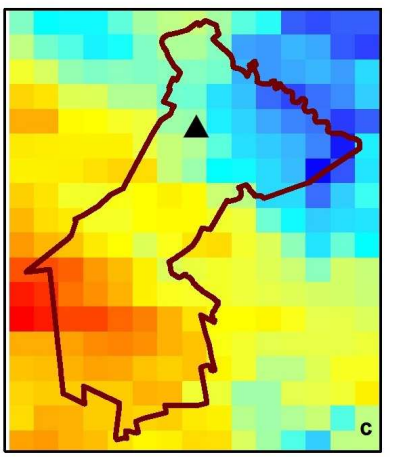

Daytime temperature (C)

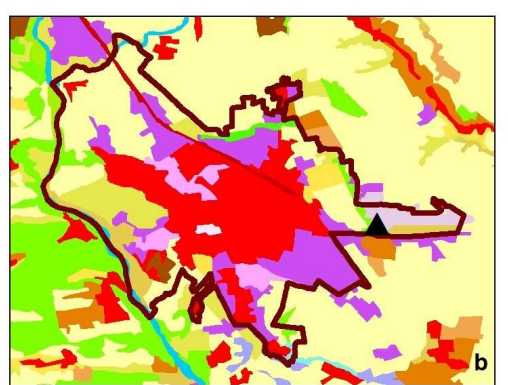

$\Delta$ weather station CLC Code \begin{tabular}{ll|l}
112 & 231
\end{tabular} $\begin{array}{lll}112 & 231 \\ 121 & 242\end{array}$

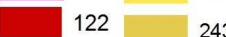

124
311

\begin{tabular}{ll|l}
132 & 313
\end{tabular}

\begin{tabular}{ll|l}
133 & 321
\end{tabular}

\begin{tabular}{ll|l}
141 & 324
\end{tabular}

\begin{tabular}{l|l|l}
142 & 411
\end{tabular}

211

\begin{tabular}{l|l|l}
221 & 512
\end{tabular}

Fig. 7. Craiova (top) and Roșiorii de Vede (below): LST data for spatial variation of the temperature $(\mathrm{a}, \mathrm{c})$; distribution of the different types of surfaces (b, d) - CLC nomenclature according to Feranec et al, 2016 
The absolute break-record of extreme heating in the studied region was registered at Roșiorii de Vede on July 24, 2007, when the maximum temperature of the day reached $42.7^{\circ} \mathrm{C}$.

Interesting fact is that Roșiorii de Vede is the smallest city among the 7 studied here, and its artificial surfaces are not the warmer on the image from the MODIS satellite. The highest temperature on the surface (around $50^{\circ} \mathrm{C}$ ) were recorded in the south-western part of the administrative territory, at the level of the arable lands, where the black soil without vegetation, heated very strongly exerting influence on the urban temperature nearby (Figure 7c, d).

\section{Conclusions}

The record heat episodes registered in 2000 and 2007 were the expression of the most severe warmings caused by the combination of several factors. These extreme phenomena are the effect of hot and dry air advection, accentuated by excessive local heating on different types of surfaces, in conditions of low air humidity and clear sky, specific to the persistence of anticyclonic activity.

The climatic factors shape a certain regional climate at the level of the Romanian Plain, imposing a general pattern valid in the spatial characterization of the extreme heating: felt with greater duration and intensity, but also more frequently in the central parts and in its southern extremity, on the Danube Valley. But a number of local influences, from the level of the various surfaces in the studied cities, introduce discontinuities in the distribution of the phenomenon.

The tendency of heating, started from 1986-1987 (Grecu et al., 2012b), is becoming more and more pronounced in recent years in the studied region, regardless of the local influences and climatic shades. Moreover, in the coming decades it is expected that the increase in the frequency of these phenomena will continue, the intensification and prolongation of heat episodes being a major danger, primarily for the health of people living in cities. 
EXTREME HEATING IN CITIES OF THE ROMANIAN PLAIN.

CERTAINTIES AND UNCERTAINTIES ABOUT THE FACTORS OF INFLUENCE

\section{REFERENCES}

Bogdan, O., 1998, 'Fréquence de réfroidissements et des réchauffements masiffs pendant le dernier siècle en Roumanie', Revue Roumaine de Géographie, 42, pp. 69-80.

Bogdan, O., Niculescu, E., 1999, Riscurile climatice din România, Institutul de Geografie, Bucureşti.

Bogdan, C., 2006, 'Patologia de caniculă - o problemă actuală de sănătate publică'. Revista Medicală Română, 53 (2-3), pp. 79-83.

Bojariu, Roxana et al. 2015, Schimbările climatice - de la bazele fizice la riscuri şi adaptare, Editura Printech, București.

Dessai, S., 2003, 'Heat stress and mortality in Lisbon Part II. An assessment of the potential impacts of climate change', International Journal of Biometeorology, 48 (1), pp. 37-44.

Feranec, J., Hazeu, G., Kosztra, B., Arnold, S. (2016), European Landscape Dynamics. CORINE Land Cover Data, section II: "CORINE land cover nomenclature." 17-27.

Gabriel, K., Endlicher, W.R., 2011, 'Urban and rural mortality rates during heat waves in Berlin and Brandenburg, Germany', Environmental Pollution, 159, pp. 2044-2050.

Grecu, F., Comănescu, L., Ghiță, C., Săcrieru, R., Toroimac, G., Vișan, M., 2012a, 'Facteurs favorables a la genese et au developement des villes de la Plaine Roumaine', in vol. Villes : Dynamiques, Climat et Environnement, ed. Taoufik El Melki, Noomene Fehri, Tunis, 51-64.

Grecu, F., Zaharia, L., Ghiță, C., Comanescu, L., Cîrciumaru, E., Albu, M. (2012b), Sisteme hidrogeomorfologice din Câmpia Română. Hazard - Vulnerabilitate - Risc, coord. Grecu, F., Editura Universității București.

European Union, Copernicus Land Monitoring Service 2018, European Environment Agency (EEA), CORINE Land Cover 2000, viewed 21 January 2020, https://land.copernic us.eu/pan-european/corine-land-cover/clc-2000

European Union, Copernicus Land Monitoring Service 2018, European Environment Agency (EEA), CORINE Land Cover 2006, viewed 21 January 2020, <https://land. copernicus.eu/pan-european/corine-land-cover/clc-2006>

Klein Tank, AMG and Coauthors 2002, 'Daily dataset of $20^{\text {th }}$-century surface air temperature and precipitation series for the European Climate Assessment', International Journal of Climatology, 22, viewed 9 April 2020, <https://www.ecad.eu/>.

Knowlton, K., Lynn, B., Goldberg, R.A., Rosenzweig, C., Hogrefe, C., Rosenthal, J., Kinney, P.L., 2007, 'Projecting heat-related mortality impacts under a changing climate in the New York City region', American Journal of Public Health, 97 (11), pp. 2028-2034.

Kusaka, H., Hara, M., Takane, Y., 2012, 'Urban climate projection by the WRF model at $3 \mathrm{~km}$ horizontal grid increment: Dynamical downscaling and predicting heat stress in the 2070's August for Tokyo, Osaka, and Nagoya metropolises, Journal of the Meteorological Society of Japan, 90B, pp. 47-64.

Masson, V., Marchadier, C., Adolphe, L., Aguejdad, R., Avner, P., Bonhomme, M., Bretagne, G., Briottet, X., Bueno, de Munck C., Doukari, O., Hallegatte, S., Hidalgo, J., Houet, T., Le Bras, J., Lemonsu, A., Long, N., Moine, M.P., Morel, T., Nolorgues, L., Pigeon, 
G., Salagnac, J.L., Viguié, V., Zibouche, K., 2014, 'Adapting cities to climate change: A systemic modelling approach, Urban Climate, 10, viewed 12 December 2019, $<$ https://doi.org/10.1016/j.uclim.2014.03.004>.

Mărculeț, C., Dumitrică, C., 2020, 'The excessive heatings in the Romanian Plain', Central European Journal of Geography and Sustainable Development, 2(1), pp. 30-37.

Mărculeț, C., Mărășoiu, D., 2016, 'Summer temperature extremes and their influence on the South-East Development Region', International Journal of Cross-Cultural Studies and Environmental Communication, Special Issue. F. Mihăilescu symposium on Applied Climatology, pp. 18-25.

Wan, Z., Hook, S., Hulley, G., 2015, MOD11A1 MODIS/Terra Land Surface Temperature/ Emissivity Daily L3 Global $1 \mathrm{~km}$ SIN Grid V006 [Data set], NASA EOSDIS Land Processes DAAC, viewed 14 March 2019, <https://doi.org/10.5067/MODIS/MOD 11A1.006/>. 